\title{
En mentor for medisinstudenten
}

Legeyrket er myteomspunnet og forbundet med respekt, prestisje og takknemlighet. De fleste medisinstudenter har jobbet hardt for å komme inn på studiet, og de trives. Møtet med prestasjonspress, menneskeskjebner og kravet om å tilegne seg store mengder fakta kan imidlertid virke overveldende. Mange blir usikre: Hva om jeg gjør noe alvorlig galt? Hvorfor opplever jeg meg så lite engasjert i enkeltpasienter? Hva gjør jeg når det ikke finnes gode løsninger? Er jeg egentlig god nok? Man går ikke umerket gjennom et medisinstudium.

Studiet har i mer enn 100 år vært preget av naturvitenskapelig tenkning. I 1980- og 1990-årene ble atferdsfag og kommunikasjon innført for å gi studentene bedre innsikt i mellommenneskelige prosesser. Likevel hevdes det fortsatt at studiet ikke forbereder leger godt nok til å forstå vanlige menneskers liv $(1,2)$. De senere årene har stadig flere tatt til orde for en mer humanistisk orientert legeutdanning (3) og å innføre ordninger med mentorer som skal støtte studentene gjennom studiet.

Mentor var en eldre mann i gresk mytologi, en venn av Odyssevs, som fikk i oppgave å ha oppsyn med sønnen Telemakus mens Odyssevs var i krig. Gjennom en populær fransk bok fra 1699 av Francois Fénelon (1651-1715), der Mentor var hovedpersonen, fikk ordet mentor sin moderne betydning som en person som bidrar med sin visdom og kunnskap og hjelper en annen med å håndtere personlige dilemmaer (4).

Mentorordninger ved medisinske fakulteter, som dukket opp i 1990-årene, er svært heterogene både hva angår organisering og formål (5). Både én til én-ordninger og gruppebaserte ordninger er vanlige. Formålene varierer. Noen har til hensikt å fremme rekruttering til forskning eller styrke karriereutvikling og valg av spesialitet, andre retter seg mot minoritetsstudenter eller kvinnelige studenter for å styrke deres posisjon og muligheter, mange er mindre spesifikke. Det er vanskelig å få en oversikt over ulike mentorordninger og hvordan de er integrert i medisinstudiet gjennom forskningslitteraturen, som gjennomgående har mange metodesvakheter, særlig hva gjelder effektstudier. Mange ordninger er ikke beskrevet.

Ordningene i Zürich og Stockholm viser hvor forskjellig mentorordninger kan være. I Zürich finnes en frivillig én til én-ordning som omfatter både medisinstudenter i tredje og sjette semester og unge, ferdige leger (6). Mentorene er erfarne klinikere. Frivillighet anses som avgjørende for ordningens suksess. I Stockholm er mentorprogrammet en obligatorisk integrert del av undervisningen, med gruppebasert mentorering, én til én-utviklingssamtaler med skriftlig, strukturert tilbakemelding og skriftlig slutteksamen om egen utvikling i essayform. Mentorene er universitetsansatte eller leger i klinisk arbeid ved universitetsklinikkene (7).

I Norge har mentorordninger vært mindre omfattende (8). I Oslo har det i mange år vært en frivillig mentorordning organisert av medisinstudentene i samarbeid med Oslo legeforening (8). En nylig evaluering av ordningen viste at det viktigste for studentene var den personlige veiledningen, muligheten til å diskutere etiske spørsmål og det å bygge et sosialt nettverk (9). Kvinnelige studenter var overrepresentert, mens studenter som var barn av leger, verken var over- eller underrepresentert. Behovet for mentorering ser altså ikke ut til å være påvirket av den innsikt i yrket man får ved å ha vokst opp med legeforeldre.

Leger bygger sin identitet gjennom hva de gjør og kan. For de fleste er det å være lege en tydelig identitetsmarkør. Vår identitet skapes også i møtet med andre: Kanskje derfor er den personlige relasjonen som en trygg mentor representerer, viktig. Rollemodeller er viktig for legers profesjonelle utvikling og viktigere enn undervisningsprogrammer (10).

Personlig og profesjonell utvikling bør være en integrert del av medisinstudiet, men vi vet lite om hvordan dette mest effektivt oppnås i praksis. Verken rekkefølge av temaer i undervisningen, dybde og detaljnivå eller ulike måter å gjennomføre undervisningen på er tilstrekkelig studert. Kan slike tiltak i det hele tatt studeres? Er det riktig - eller mulig - å anlegge effektstudier av personlig og profesjonell utvikling? Eller skal vi bare våge å stole på at langsiktige personlige relasjoner mellom leger og medisinstudenter er et gode? Det blir spennende å se hva de nåværende initiativene ved de fire medisinske fakultetene i Norge fører til.

\section{Pål Gulbrandsen}

pal.gulbrandsen@medisin.uio.no

Pål Gulbrandsen (f. 1955) er professor i helsetjenesteforskning ved Universitetet i Oslo og seniorforsker ved Akershus universitetssykehus med særlig interesse for lege-pasient-forholdet og klinisk kommunikasjon. Han er spesialist i samfunnsmedisin og tidligere spesialist i allmennmedisin. Han har ledet utredningen av en mentorordning ved Det medisinske fakultet, Universitetet i Oslo.

Forfatter har fylt ut ICMJE-skjemaet og oppgir ingen interessekonflikter.

\section{Litteratur}

1. Merok E. Om helsens skjulte natur. Tidsskr Nor Lægeforen 2001: 121: 1610-2.

2. Johansson KA, Ohldieck C, Aase M et al. Skjebnezapping -medisinsk grunnopplæring, legestudenters dannelse og den etiske fordring. Tidsskr Nor Lægeforen 2001; 121: 1618-21.

3. Schei E, Gulbrandsen A. red. Forstår du, doktor? Mot en humanistisk legeutdanning. Oslo: Tano Aschehoug, 2000

4. Wikipedia. Om mentor. https://en.wikipedia.org/wiki/Mentor (21.5.2015)

5. Frei E, Stamm M, Buddeberg-Fischer B. Mentoring programs for medical students - a review of the PubMed literature 2000-2008. BMC Med Educ 2010; 10: 32

6. Buddeberg-Fischer B. Stamm M. Mentoring in der Medizin. Formen, Konzepte und Erfahrungen. Bericht über Mentoring-Programme am Universitätsspital und an der Medizinischen Fakultät der Universität Zürich 2002-2011. Bern: Staatssekretariat für Bildung und Forschung, 2012

7. Kalén S. Mentorship for medical students - space for something else. Thesis. Stockholm: Karolinska Institutet, 2013.

8. Berg E, Nicolaisen C. Mentorgrupper for medisinstudenter - et bidrag til personlig modning fram mot legeyrket? Noen erfaringer med studentgrupper ved norske universiteter. Utposten 2007; 36: $31-4$

9. Kalaaji A, Vadseth L, Mariero LH. Er mentorordningen på medisinsk fakultet i Oslo tilfredsstillende? En spørreundersøkelse. Esculap 2014; 94: 32-7.

10. Birden H, Glass N, Wilson I et al. Teaching professionalism in medical education a best evidence medical education (BEME) systematic review. BEME Guide No. 25. Med Teach 2013; 35: e1252-66. 